\title{
PKM Sosialisasi Penggunaan Antibiotik dan Efek Penyalahgunaan Antibiotik Guna Pengendalian Resistensi Antibiotik Di Desa Sanrobone Kecamatan Sanrobone Kabupaten Takalar
}

\author{
Rasfayanah $^{1}$, Arni Isnaini Arfah ${ }^{2}$, Zulfahmidah $^{1}$ \\ ${ }^{1}$ Depertemen Biokimia, Fakultas Kedokteran, Universitas Muslim Indonesia \\ ${ }^{2}$ Depertemen Fisiologi, Fakultas Kedokteran, Universitas Muslim Indonesia \\ *Email Korespondensi: zulfahmidah@gmail.com \\ Telp: +62-82345319900
}

\begin{abstract}
ABSTRAK
Istilah antibiotik mencakup semua antimikroba yang digunakan dalam pengobatan dan profilaksis infeksi bakteri. Antibiotik merupakan obat yang sering diresepkan untuk pasien namun sering terjadi penggunaan yang tidak tepat dan berakibat terjadinya resistensi terhadap kuman. Hal ini terjadi karena kurangnya pengetahuan masyarakat tentang penggunaan antibiotik yang tepat sehingga menyebabkan resistensi antibiotik. Saat ini, pengetahuan masyarakat tentang resistensi antibiotik sangat rendah. Hasil penelitian yang dilakukan WHO dari 12 negara termasuk Indonesia, sebanyak 53-62\% berhenti minum antibiotik ketika merasa sudah sembuh. Resistensi antibiotik saat ini menjadi ancaman terbesar bagi kesehatan masyarakat global, sehingga WHO mengkoordinasi kampanye global untuk meningkatkan kesadaran dan perilaku masyarakat terhadap antibiotik. Metode Yang digunakan adalah memberikan penyuluhan Sosialisasi Penggunaan Antibiotik dan Efek Penyalahgunaan Antibiotik Guna Pengendalian Resistensi Antibiotik di Desa Sanrobone Kecamatan Sanrobone Kabupaten Takalar Sulawesi Selatan. Target luaran untuk enambah pengetahuan dan pemahaman masyarakat mengenai Penggunaan Antibiotik dan Efek Penyalahgunaan Antibiotik, memberikan bahan ajar seperti banner, poster, leaflet bergambar yang mudah dimengerti dan dapat dipergunakan setelah kegiatan ini. Berdasarkar dari data hasil kuesioner (pre dan post test) pada peserta, didapatkan peningkatan pemahaman tentang Penggunaan Antibiotik dan Efek Penyalahgunaan Antibiotik Guna Pengendalian Resistensi Antibiotik. Dimana jumlah jawaban benar meningkat pada hasil pre-test (evaluasi). Dari hasil evaluasi tersebut, kami tim pengabdian kepada masyarakat menyimpulkan keberhasilan kegiatan ini, dimana masyarakat jadi lebih mengetahui apa itu antibiotik, bagaimana penggunaannya sehingga tidak menimbulkan resistensi dikemudan hari.
\end{abstract}

Kata Kunci : antibiotik; resistensi antibiotik; desa Sanrobone Kecamatan Sanrobone; kabupaten takalar

\begin{abstract}
Orgasm includes all antimicrobials used in the treatment and prophylaxis of bacterial infections. Antibiotics are drugs that are often prescribed to patients but are often used inappropriately and result in resistance to germs. This occurs due to the lack of public knowledge about the use of appropriate antibiotics, which causes antibiotic resistance. Currently, the public regarding antibiotic resistance is very low. The results of a study conducted by WHO from 12 countries including Indonesia, showed that 53-62\% stopped taking antibiotics when they recovered. Antibiotic resistance is currently the biggest threat to global public health, so WHO is coordinating a global campaign to increase public awareness and behavior towards antibiotics. The method is provision of Antibiotic Socialization and the Effects of Antibiotic Abuse to Control Antibiotic Resistance in Sanrobone Village, Sanrobone District, Takalar Regency, South Sulawesi. Output target is Increase public knowledge and understanding about the Use of Antibiotics and the Effects of Antibiotic Abuse, provide teaching materials such as banners, posters, illustrated leaflets that are easy to use and can be used after this activity. Based on the questionnaire result data (pre and post-test) on the participants, there was an increase in understanding of the use of antibiotics and the effects of antibiotic abuse to control antibiotic resistance. Where are the numbers of
\end{abstract}


correct answers increases in the pre-test (evaluation) results. From this evaluation, our community service team concluded that this activity, in which the public is more aware of what antibiotics are, how to use them so that they do not cause resistance in the morning.

Keywords: antibiotics; antibiotic resistance; Sanrobone village; Sanrobone district; Takalar district

\section{PENDAHULUAN}

Istilah antibiotik mencakup semua antimikroba yang digunakan dalam pengobatan dan profilaksis infeksi bakteri. Antibiotik sebagai obat untuk mengobati penyakit infeksi harus digunakan secara rasional, tepat dan aman. Pemakaian obat dikatakan rasional jika memenuhi kriteria sesuai dengan indikasi penyakit, tersedia setiap saat dengan harga yang terjangkau, diberikan dengan dosis yang tepat, cara pemberian dengan interval waktu yang tepat, lama pemberian yang tepat, tepat indikasi, tepat pasien dan obat yang diberikan harus efektif dengan mutu yang terjamin dan aman. Penggunaan obat yang tidak rasional menyebabkan kerugian antara lain pemborosan biaya kesehatan atau pengobatan menjadi lebih mahal, resiko efek samping, perawatan penderita lebih lama, menurunkan kualitas pelayanan kesehatan, dapat menghilangkan sensitivitas bakteri terhadap antibiotik dan memperluas resistensi bakteri(Sari, 2015).

Antibiotik merupakan obat yang sering diresepkan untuk pasien namun sering terjadi penggunaan yang tidak tepat dan berakibat terjadinya resistensi terhadap kuman(Ilmiah, 2017). Hal ini terjadi karena kurangnya pengetahuan masyarakat tentang penggunaan antibiotik yang tepat sehingga menyebabkan resistensi antibiotik(Moorthy, 2013). Saat ini, pengetahuan masyarakat tentang resistensi antibiotik sangat rendah. Hasil penelitian yang dilakukan WHO dari 12 negara termasuk Indonesia, sebanyak 53-62\% berhenti minum antibiotik ketika merasa sudah sembuh. Resistensi antibiotik saat ini menjadi ancaman terbesar bagi kesehatan masyarakat global, sehingga WHO mengkoordinasi kampanye global untuk meningkatkan kesadaran dan perilaku masyarakat terhadap antibiotik (Ilmiah, 2017).

\section{METODE PELAKSANAAN}

\subsection{Solusi dan Target Luaran}

Solusi Yang Ditawarkan Untuk Mitra adalah Penyuluhan Sosialisasi Penggunaan Antibiotik dan Efek Penyalahgunaan Antibiotik Guna Pengendalian Resistensi Antibiotik di Desa Sanrobone Kecamatan Sanrobone Kabupaten Takalar. Target luaran yang diharapkan adalah

1. Menambah pengetahuan dan pemahaman masyarakat mengenai Penggunaan Antibiotik 
di Desa Sanrobone Kecamatan Sanrobone Kabupaten Takalar.

2. Menambah pengetahuan kepada masyarakat mengenai Efek Penyalahgunaan Antibiotik Guna Pengendalian Resistensi Antibiotik di Desa Sanrobone Kecamatan Sanrobone Kabupaten Takalar.

3. Masyarakat menjadi lebih baik dalam penggunaan antibiotik.

4. Publikasi ilmiah pada Jurnal ber ISSN/Prosiding.

5. Publikasi pada media massa cetak/online.

6. Perbaikan tata nilai masyarakat dalam bidang kesehatan.

\subsection{Lokasi Kegiatan Pelaksanaan (contoh)}

Kegiatan Pelaksanaan pengabdian ini diadakan di Desa Sanrobone Kecamatan Sanrobone Kabupaten Takalar dimana akan melibatkan seluruh anggota masyarakat yang ada di lokasi tersebut.

\subsection{Metode Kegiatan}

a. Secara Umum

Sosialisasi Penggunaan Antibiotik dan Efek Penyalahgunaan Antibiotik Guna Pengendalian Resistensi Antibiotik di Desa Sanrobone Kecamatan Sanrobone Kabupaten Takalar

b. Secara khusus

1. Melakukan koordinasi dengan pihak yang berwenang di Desa Sanrobone Kecamatan Sanrobone Kabupaten Takalar.

2. Mengetahui dan mendata jumlah peserta yang akan ikut berpartisipasi dalam kegiatan ini.

3. Mendata tingkat pengetahuan peserta mengenai Penggunaan Antibiotik dan Efek Penyalahgunaan Antibiotik Guna Pengendalian Resistensi Antibiotik di Desa Sanrobone Kecamatan Sanrobone Kabupaten Takalar.

4. Melakukan penyuluhan mengenai Penggunaan Antibiotik dan Efek Penyalahgunaan Antibiotik Guna Pengendalian Resistensi Antibiotik di Desa Sanrobone Kecamatan Sanrobone Kabupaten Takalar dengan menggunakan alat bantu seperti banner, poster, flipchart, dan leaflet bergambar sehingga lebih mudah dimengerti.

5. Melakukan evaluasi untuk mengetahui keberhasilan dari kegiatan ini. 


\section{HASIL DAN PEMBAHASAN}

Berdasarkar dari data hasil kuesioner (pre dan post test) pada peserta, didapatkan peningkatan pemahaman tentang Penggunaan Antibiotik dan Efek Penyalahgunaan Antibiotik Guna Pengendalian Resistensi Antibiotik. Dimana jumlah jawaban benar meningkat pada hasil pre-test (evaluasi).

Dari hasil evaluasi tersebut, kami tim pengabdian kepada masyarakat menyimpulkan keberhasilan kegiatan ini, dimana masyarakat jadi lebih mengetahui apa itu antibiotik, bagaimana penggunaannya sehingga tidak menimbulkan resistensi dikemudan hari.

\section{KESIMPULAN DAN SARAN}

Setelah mengikuti kegiatan, peserta mampu memahami lebih baik mengenai penggunaan antibiotik dan memahami lebih baik mengenai efek penyalahgunaan antibiotik guna pengendalian resistensi antibiotik. Kegiatan ini sebaiknya dilakukan secara berkelanjutan agar dapat terus mencegah terjadinya penyalahgunaan antibiotik guna pengendalian resistensi antibiotik dan kegiatan dilakukan dalam skala lebih besar dengan melibatkan sebagian besar sivitas akademika UMI.

\section{Ucapan Terima Kasih}

Kami ucapkan terima kasih kepada perangkat desa Sanrobone Makassar dan kepada LPMD Universitas Muslim Indonesia

\section{DAFTAR PUSTAKA}

1. Dwiprahasto, I., Kristin, E. and Qibtiyah, M. (2011) Pedoman Umum Penggunaan Antibiotik. Jakarta: Kementrian Kesehatan RI.

2. Ilmiah, P. (2017) 'Evaluasi tingkat pengetahuan masyarakat tentang penggunaan antibiotik di kabupaten klaten universitas muhammadiyah surakarta'.

3. Moorthy, Y. T. (2013) 'Gambaran Pengetahuan Masyarakat Terhadap Penggunaan Antibiotik Di Puskesmas Padang Bulan Medan - 123dok'.

4. Sari, W. D. M. (2015) 'No Title', STUDI PERBANDINGAN KEPATUHAN PENGGUNAAN ANTIBIOTIK DI APOTEK BHUMYAMCA II DAN TIARA 2.

5. Suwandi (1992) 'MEKANISME KERJA ANTIBIOTIK - E-JURNAL'.

6. Yuliati, D. R. D. and Si, M. (2018) 'Resistensi Antimikroba di Indonesia'.

7. Aslam, M., Tan, C.K.,Prayitno, A.,2003, Farmasi Klinis(Clinical Pharmacy) : Menuju Pengobatan Rasional dan Penghargaan Pasien, 321,PT. ElexMedia Komputindo, kelompok Gramedia, Jakarta.

8. Badan POM RI., 2008, Information Obat Nasional Indonesia, Badan Pengawas Obat dan Makanan Republik Indonesia, Jakarta.

9. Cunha, B.A., 2002, Antibiotic Essentials, State University of New York School of Medicine, Physicians Press, New York.

10. Depkes RI., 1988, Buku Pedoman Penatalaksanaan Penderita Infeksi Saluran Pernafasan Akut (ISPA) dan Diare untuk Petugas Kesehatan, hal. 19- 20, 99, 155-159, Departemen Kesehatan RI, Jakarta. 